The Historical Journal, 6o, 4 (2017), pp. 1097-1123 C Cambridge University Press 2017 This is an Open Access article, distributed under the terms of the Creative Commons Attribution licence (http://creativecommons.org/licenses/by/4.o/), which permits unrestricted re-use, distribution, and reproduction in any medium, provided the original work is properly cited.

doi: $10.1017 /$ Soo $18246 X_{1} 6000571$

\title{
THE TRIUMPH OF THE STATE: SINGAPORE'S DOCKWORKERS AND THE LIMITS OF GLOBAL HISTORY,$$
\text { c. } 1920-1965 *
$$$$
\text { GARETH CURLESS }
$$

The University of Exeter

\begin{abstract}
A B S T R A C T. Labour history has been revitalized by the global turn. It has encouraged historians to look beyond national frameworks to explore issues relating to mobility and inter-territorial connection. This article, while accepting the benefits of a global approach, argues that historians should not lose sight of the factors that constrain mobility or lead to the collapse of cross-border exchanges. Singapore's dockworkers were at the forefront of the island's anti-colonial campaigns of the I94Os and I950s. Inspired by anti-colonial movements elsewhere in the world, dockworkers drew on international discourses relating to self-determination to place their local struggles in a global context. This activism, however, coincided with the emergence of countervailing forces, including the universalization of the nation-state and the rise of state-led developmentalism. In this context, dockworkers' internationalism came to be regarded as a threat to state sovereignty and development. As a result, once Singapore achieved independence the ruling People's Action Party encouraged dockworkers to abandon their globalized outlook in the name of modernization and nation building. Global history, then, should be as much about the rise of the national as the transnational, and the loss of connection as the forging of inter-territorial networks.
\end{abstract}

Labour historians have been particularly attuned to the global turn. Over the last decade, many practitioners have come to regard global history as a way of revitalizing a subfield that entered into a period of relative decline during the 1990s. ${ }^{1}$ As a result, labour historians have become not only more global in their outlook, but they have also begun to pay greater attention to subjects

Department of History, University of Exeter, EX4 4RJ g.m.curless@exeter.ac.uk

* I would like to thank Sujit Sivasundaram, Loh Kah Seng, Peter Cole, Duncan Money, and the anonymous reviewers for their comments and invaluable suggestions on earlier drafts of the article. Thanks must also go to Revathy Sivasamboo for her help translating the Tamil interviews used in the article. The research for this article was funded by the Economic and Social Research Council (grant ref: ES/Koo8749/1).

${ }^{1}$ Marcel van der Linden, 'The promise and challenges of global labour history', International Labor and Working Class History, 82 (2012), pp. 57-76. 
that speak to contemporary concerns associated with globalization. ${ }^{2}$ This has given rise to a number of studies considering a diverse array of subjects, including 'global' occupations, forms of free and unfree labour migration, and the global dimensions of working-class formation. ${ }^{3}$ The benefits of this global approach are immeasurable. Among other things, it has highlighted the importance of studying labour in globalized sectors over the longue durée; it has brought into question the teleological assumption that labour movements inevitably develop a national character; and it has underscored the point that workingclass formation was driven by processes that occurred across territorial borders. 4

Nowhere has the global turn within labour history been more apparent than in the study of port cities and maritime labour networks. 5 The attraction of ports for global labour historians is self-evident. As Frederick Cooper writes, 'Ports are not simply specific instances of a general phenomenon; they are connected to one another. Whatever the spatial fixity of a port, the reason for its existence was its links with other specific locations. ${ }^{6}$ However, although a port's existence may have depended upon its status as a nodal point within the global economy, port cities were shaped by more than just the flow of commodities from one location to the next. ${ }^{7}$ Alice Mah has described port cities as lying 'at the edge between black and blue' - 'exotic places of cosmopolitanism and vibrant cultural exchange connected to the blue of sea, sky and dreams', but also "black" places of crime, violence, poverty and social exclusion'. ${ }^{8}$ These contradictions were embodied by dockworkers, the occupational group most commonly associated with port cities. Dockworkers have been defined by

${ }^{2}$ Matthias van Rossum, 'Redirecting global labor history?', in Cátia Antunes and Karwan Fatah-Black, eds., Explorations in history and globalization (Oxford, 2016), pp. 47-62.

${ }^{3}$ Jan Lucassen, 'Writing global history, c. 180o-1940: a historiography of concepts, periods and geographical scope', in Jan Lucassen, ed., Global labour history: a state of the art (New York, NY, 2008), pp. 39-84; Marcel van der Linden, 'The "globalization" of labor and working class history and its consequences', International Labor and Working Class History, 65 (2004), pp. $13^{6}$ $5^{6 .}$

4 Jonathan Hyslop, 'The imperial working class makes itself "white": white labourism in Britain, Australia and South Africa before the First World War', Journal of Historical Sociology, 12 (1999), pp. 398-421.

${ }^{5}$ Leon Fink, Sweatshops at sea: merchant seamen in the world's first globalised industry (Chapel Hill, NC, 2011); Peter Linebaugh and Marcus Rediker, The many-headed hydra: the hidden history of the revolutionary Atlantic (London, 2000); Matthias van Rossum, 'The rise of the Asian sailor? Inter-Asiatic shipping, the Dutch East India Company and maritime labour markets (1500-1800)', in S. Bhattacharya, ed., Towards a new history of work (New Delhi, 2014), pp. 180-213; Jonathan Hyslop, 'Oceanic mobility and settler-colonial power: policing the global maritime labour force in Durban Harbour, c. 1890-1910', Journal of Transport History, 36 (2015), pp. 248-67.

${ }^{6}$ Frederick Cooper, 'Dockworkers and labour history', in Sam Davies et al., eds., Dock workers: international exploration in comparative labour history, I790-1970, II (Aldershot, 2000), p. 524.

7 Kenneth McPherson, 'Port cities as nodal points of change: the Indian Ocean, 189os1920s', in Lelia Fawz and Christopher Bayly, eds., Modernity and culture from the Mediterranean to the Indian Ocean (New York, NY, 2002), pp. 75-95.

8 Alice Mah, Port cities and global legacies: urban identity, waterfront work and radicalism (Basingstoke, 2014), p. 27. 
their labour militancy, close community ties, and radical anti-authoritarian politics but the casual nature of dockwork also gave rise to discriminatory employment practices often linked to racial or ethnic chauvinism, criminal networks, and shadow economies. 9 These contradictions serve as a useful reminder of the potential pitfalls of global approaches to labour history. While the recent focus on workers' mobility has highlighted the connections between distant parts of the world, forcing labour historians to rethink the boundaries of working-class imaginations, one should not necessarily assume that interaction across space and time, or the concentration of migrant workers into shared neighbourhoods, inevitably resulted in mutual understanding and class unity. As Philip Bonner, Jonathan Hyslop, and Lucien van der Walt argue: 'Cosmopolitan contexts can as easily accentuate differences as limit their significance.' ${ }^{\circ}$

This article sets out to explore these contradictions by focusing on Singapore's dockworkers in the period from the 1920 s through to the early 1960s. Historians are increasingly challenging the view that colonial Singapore was a plural society where sharp racial divisions resulted in a highly segregated population. ${ }^{11}$ Instead, the city has been recast as 'a world motion', to borrow Takashi Shiraishi's term, shaped by a cosmopolitanism that produced a multitude of hybrid cultural forms, discourses, and practices. ${ }^{12}$ Historians have been slow to apply this revised understanding of colonial Singapore to the experience of 'ordinary' migrants, and accounts continue to emphasize the clannish and insular nature of the island's working-class population. ${ }^{13}$ In contrast, this article argues that while dockworkers' livelihoods depended upon intimate ties of kinship and ethnicity, their horizons were not limited by such parochialisms. This was most apparent during the 1940s and 195os, when dockworkers took inspiration from global discourses and events relating to anti-colonialism to express their localized struggle against the inequities of colonial rule through rallies, strikes, trade unions, and political parties. However, as Sunil Amrith argues, 'thinking of Singapore as a "mobile city"

9 Colin J. Davis, 'Formation and reproduction of dockers as an occupational group', in Davies et al., eds., Dock workers, pp. 542-59.

${ }^{10}$ Philip Bonner, Jonathan Hyslop, and Lucien van der Walt, 'Rethinking worlds of labour: Southern African labour history in international context', African Studies, 66 (2007), pp. 13767 .

${ }^{11}$ Tim Harper and Sunil Amrith, 'Sites of Asian interaction', Modern Asian Studies, $4^{6}$ (2012), pp. 249-57; Tim Harper, 'Globalism and the pursuit of authenticity: the making of a diasporic public sphere in Singapore', Sojourn: Journal of Social Issues in Southeast Asia, 12 (1997), pp. 261-92.

${ }_{12}$ Takashi Shiraishi, An age in motion: popular radicalism in Java, I912-1926 (Ithaca, NY, 1990).

13 Jim Warren, Rickshaw Coolie: a people's history of Singapore (Singapore, 2003); Carl A. Trocki, Singapore: wealth, power and the culture of control (Oxford, 20o6). 
must not...blind us to the highly constrained nature of that mobility'. ${ }^{14}$ In the case of Singapore's dockworkers, the flowering of their political activism coincided with the emergence of countervailing forces, including the closing of territorial borders throughout Asia, the universalization of the nation-state, and the rise of muscular state-led developmentalism. In this context, it became increasingly difficult for Singapore's dockworkers to think or act beyond the boundaries of the island city-state: established patterns of circulatory migration were curbed with the imposition of stricter immigration controls; transnational networks of anti-colonial activism collapsed as the focus increasingly shifted to the more immediate task of national liberation; and greater limits on political freedoms were imposed, as first the colonial authorities and later the post-colonial state demanded that dockworkers accept more stringent forms of labour discipline in the name of development and modernization. This contributed to a passivity and insularity among dockworkers, who began to think of their personal struggles, not in terms of global anti-colonial activism, but in relation to the task of nation-state building. What this suggests is that while global approaches have opened up exciting new avenues of research, historians should remain sensitive to the limits of global history as a methodological approach and consider the ways in which transnational networks break down.

\section{I}

By the early twentieth century, Singapore had become a port of global significance, serving as an export hub for raw materials from Malaya and a transhipment centre for vessels travelling to and from East Asia. ${ }^{15}$ Operations in the port were the responsibility of the publicly owned Singapore Harbour Board (SHB), which was established in 1913. The port industry was one of the largest employers in Singapore, employing approximately 4,ooo Chinese and Indian dockworkers by the early $1920{ }^{16}{ }^{6}$ The SHB, however, did not directly employ its workforce; it relied on private contractors, the most prominent of which were the Cantonese Labour Syndicate, the Tanjong Pagar Labour Company, and the Indian Labour Company. In exchange for supplying labour, the SHB distributed to the contractors a portion of the fee charged to the shipping agents, who then paid the dockworkers' wages through an intermediary, the mandore (foreman). In addition to wages, the contractors provided

\footnotetext{
${ }^{14}$ Sunil Amrith, 'Mobile city and the Coromandel coast: Tamil journeys to Singapore, 19201960', Mobilities, 5 (2010), p. 238.

${ }^{15}$ Lin Sien, 'The port of Singapore', in Kernial Singh Sandhu and Paul Wheatley, eds., Management of success: the moulding of modern Singapore (Singapore, 1989), pp. 314-36.

${ }^{16}$ G. W. A. Trimmer, A short history of the port of Singapore (Singapore, 1922), p. 8. The categories of 'Chinese', 'Indian', and 'Malay' are problematic, of course, since they are colonial constructions that elide important ethnic and linguistic differences. Jan van der Putten, 'Negotiating the Great Depression: the rise of popular culture and consumerism in early 1930 Malaya', Journal of Southeast Asian Studies, $4^{1}$ (2010), pp. 25-6 fn. 18.
} 
dockworkers with food, accommodation, and, in some cases, return travel to China or India. ${ }^{17}$ Such arrangements were common to many industries in Singapore for they enabled employers to adjust the supply of labour according to the ebb and flow of demand without incurring the costs associated with maintaining a permanent workforce. ${ }^{18}$

The majority of dockworkers were single male migrants, recruited directly from India or China, contractors typically employing one group or the other. ${ }^{19}$ The dependence upon indirect forms of recruitment, and the limited access to relevant SHB files, means that it is impossible to be certain about the terms or length of dockworkers' employment in the port during the first half of the twentieth century. What we do know is that under the contractor system, dockworkers were employed on a daily basis and that by the late 193 os wages were reported to be $5^{\mathrm{o}}$ to 90 cents per shift. ${ }^{20}$ It also seems likely that although employed as casual labourers, dockworkers worked regularly in the port for the duration of their time in Singapore, the contractors rotating gangs to ensure an equitable share of employment.

The arrival of large numbers of Chinese and Indian labourers seeking employment in the port of Singapore was part of the broader wave of Asian migration that saw millions of migrants disperse across the Indian Ocean and Southeast Asia from $185^{\circ}$ to $1930 .{ }^{21}$ Adam McKeown has challenged those historians who have portrayed Asian migration in this period as exceptional when compared with contemporaneous European migration. McKeown argues that Asian migration was driven by the same globalizing forces as European migration and that while coercion by colonial states and European capital played a part, historians should not lose sight of Asian migrants' autonomy or the role of Asian commercial and familial networks in facilitating this mass movement of people. ${ }^{22}$ In light of this, the historian's task is to specify the context in which migrants travelled to destinations such as Singapore, the role and limits of the coercion involved in the recruitment process, and the agency of

17 The National Archives (TNA) CO 273/641/6, Monthly Review of Chinese Affairs (MRCA), Sept. 1938, p. 16. Singapore National Archives (SNA), interview with Sundarajulu Lakshmana Perumal, reel number: 0oo173/2.

18 The structure of Singapore's labour market during the first half of the twentieth century is best explained by W. G. Huff, The economic growth of Singapore: trade and development in the twentieth century (Cambridge, 1994), pp. ${ }^{150-79 .}$

19 TNA, CO 273/641/6, MRCA, Sept. 1938, p. 16; SNA, interview with Sundarajulu Lakshmana Perumal, reel number: ooo1 $73 / 2$.

${ }^{20}$ TNA, CO 273/641/6, MRCA, Sept. 1938, p. 16.

${ }^{21}$ Sunil Amrith, Migration and diaspora in modern Asia (Cambridge, 2011), especially chs. 1 and 2.

${ }^{22}$ Adam McKeown, Melancholy order: Asian migration and the globalization of borders (New York, NY, 2011), pp. 1-18 and 43-65. For an example of the Atlantic exceptionalism argument, see Dirk Hoerder, Cultures in contact: world migration in the second millennium (Durham, NC, 2002). 
Asian migrants in their attempts to secure improved livelihoods for themselves and their families. ${ }^{23}$

In the case of Singapore's Chinese and Indian dockworkers, the majority of those recruited would have had their passage paid for by the labour company or a recruiting agent acting on behalf of the contractor. ${ }^{24}$ In return, dockworkers were expected to work for the contractor until this debt was repaid. This was a fairly typical arrangement, as work by Kaoru Sugihara has documented. ${ }^{25}$ Indeed, the centrality of labour contractors and recruiting agents to the economies of the Indian Ocean region and Southeast Asia is indicative of a wider point made by historians such as Sugata Bose. ${ }^{26}$ The consolidation of colonial rule and the expansion of European enterprise from the mid-nineteenth century onwards transformed these regional economies but this process relied on established Asian networks and was in many instances dependent upon Asian intermediaries to provide the impetus and capital for closer economic integration. ${ }^{27}$ In this respect, labour intermediaries, such as contractors and recruiting agents, were not an archaic hangover from the pre-colonial era; they were both products and agents of globalizing forces. ${ }^{28}$

The contractor system highlights the agency of Asian intermediaries but it also underscores the fact that the autonomy of individual dockworkers was more circumscribed. Many dockworkers would have arrived in Singapore with the objective of saving money that could then be remitted to family in India or China, the ultimate aim being to return home with sufficient capital to invest in land or to become a successful merchant. Of course, the combination of low wages and debts incurred as a result of the journey to Singapore meant that many dockworkers never realized these objectives. In the majority of cases, dockworkers became 'sojourners', alternating between two or three years of paid employment in the port and return trips to China or India for periods of up to six months. ${ }^{29}$ Dockworkers' autonomy was further limited as a result of the legislation that regulated the contractor system. The 1920 Labour Ordinance, for example, established the penalties for labour-related offences,

23 Amrith, Migration and diaspora, p. 10.

24 SNA, Sundarajulu Lakshmana Perumal, reel number: ooo173/1.

${ }^{25}$ Kaoru Sugihara, 'Patterns of Chinese emigration to Southeast Asia, 1869-1939', in Kaoru Sugihara, ed., Japan, China and the growth of the Asian international economy, I850-1949 (Oxford, 2005), pp. 244-74.

${ }_{26}$ Sugata Bose, A hundred horizons: the Indian Ocean in an age of global empire (Cambridge, MA, 2006); Sunil Amrith, Crossing the Bay of Bengal: the furies of nature and the fortunes of migrants (Cambridge, MA, 2013).

${ }^{27}$ Sugata Bose, 'Blackbirders refitted? The journeys of capitalists and labourers in the Indian Ocean, 183 os-1930s', in Jayati Bhattacharya and Coonoor Kripalami, eds., Indian and Chinese immigrant communities: comparative perspectives (Singapore, 2015), pp. 3-12.

${ }_{28}$ Ulbe Bosma, Elise van Nederveen Meerkerk, and Aditya Sarkar, 'Mediating labour: an introduction', International Review of Social History, 57 (2012), p. 5 .

29 SNA, interview with Sellan Sivalingkam, reel number: oo1248/2; SNA, interview with Moorthi Thatchanna, reel number: ooog9o/1. 
such as absenteeism and disobedience, with punishments ranging from fines to imprisonment for up to twelve months. The Ordinance also set out employers' obligations with regard to terms of employment and minimum standards for housing and sanitation facilities. $3^{\circ}$ However, while contraventions of these regulations by employers were reported to be widespread, cases were rarely brought against contractors. ${ }^{31}$ In contrast, dockworkers were routinely penalized for workplace infractions. In 1937, for example, seven dockworkers were prosecuted for criminal intimidation for their part in instigating a protest against the Indian Labour Company. $3^{2}$ Such episodes expose the discrepancy between the rhetoric of freedom of contract and the realities of repressive colonial labour regimes throughout the British empire, where strict legal codes were used to enforce discipline, penalize a wide range of workplace violations, and suppress labour rights. 33

The SHB's dependence on contractors for the supply of labour meant that British officials exercised very little direct control over the recruitment process or the supervision of the labour force. 34 Instead, the SHB relied on the mandores and locally recruited administrative staff to enforce discipline on the wharves. 35 Such limited contact meant that dockworkers had few opportunities to dispel colonial prejudices, British officials associating employment in the port with gambling, criminality, and opium abuse. $3^{6}$ These specific criticisms of dockworkers were exacerbated by a deeper, racialized view of Chinese and Indian labourers shared by British officials and European employers throughout Singapore and Malaya. Tamil labourers were characterized as docile but lazy, requiring constant supervision and guidance. In contrast, the Chinese workforce was regarded as industrious but more strike-prone and open to political agitation. 37 Such crude racial stereotyping was not unique to Singapore. Throughout the British empire, it was widely believed that African and Asian workers were in the process of acculturating to the industrial environment, incapable of adapting to the regular work rhythms of industrial capitalism,

$3^{\circ}$ TNA, CO 274/15, Labour ordinance 1920 (Singapore, 1920).

31 'Alleged defamation in Singapore article', Singapore Free Press and Mercantile Advertiser, 27 Aug. 1937, p. 7; 'Labour company partner refuses to disclose charge to SHB', Singapore Free Press and Mercantile Advertiser, 28 Aug. 1937, p. 9 .

$3^{2}$ 'Strike agitators sentenced', Singapore Free Press and Mercantile Advertiser, 3 Mar. 1937, p. 3.

33 Douglas Hay and Paul Craven, eds., Masters, servants, and magistrates in Britain and the empire, I562-I955 (Chapel Hill, NC, 2004).

34 'Inquiry samples an SHB foreman's Malay', Straits Times, 10 Aug. 1957, p. 8.

35 SNA, interview with Lim Kit Long, reel number: oo2427/o6/o3; SNA, interview with Suppiah Kathan, reel number: $001003 / 2$.

$3^{6}$ SNA, interview with Roland Milne, reel number: ooo $447 / 64 / 34$.

37 John Solomon, A subaltern history of the Indian diaspora in Singapore: gradual disappearance of untouchability, I872-I965 (Oxford, 2016), pp. 56-67; K. Vtviane Frings, "The turbulent but commercially valuable Chinese": a comparison of French and British colonial policies towards the Chinese in Southeast Asia', Itinerario, 19 (1995), pp. 48-68. 
and that where casual labour prevailed social disorder usually followed. ${ }^{8}$ Such views were reflected in evidence submitted to a 1918 commission of inquiry by J. B. Nicholson, chairman of the SHB, who complained that: 'This class of men is always changing. Most of them are daily men, the coal coolie is paid by the job. He comes in and earns say a dollar... and then he goes away.'39

Far from being ever-changing anonymous units of labour, however, the stevedore and wharf gangs constituted a distinct social group, often with shared ethnic and kinship ties. The labour gangs, which were comprised of either Indian or Chinese dockworkers, also tended to be relatively stable units as experienced gangs were more likely to secure employment and their members less likely to suffer injury. These ties were further strengthened by the gangs' relationship with a common patron: the mandore. The mandores occupied an ambiguous position in the port industry. On the one hand, they were dependent upon the gangs' labour to maintain their role as the contractor's trusted intermediary. At the same time, the mandores' responsibility for recruiting dockworkers, enforcing discipline, and distributing wages meant that they had substantial power. Mandores could demand bribes in exchange for employment and secure work for preferred labourers, as was common in many ports throughout the world. $4^{\circ}$ In addition to this complex patron-client relationship, the gangs possessed their own 'moral economies', which controlled pilferage and determined the speed and intensity of work, and whether a gang would support strike action. ${ }^{4^{1}}$ In other words, while the British authorities tended to conflate casual labour with disorder, dockworkers' social relations were more complex than colonial prejudices implied, governed as they were by ties of ethnicity, kinship, and patronage.

Of course, the majority of dockworkers did not arrive in Singapore as 'dockworkers'. Most were unskilled labourers, more accustomed to agricultural work than the industrial environment of the port. $4^{2}$ Newly arrived migrants were often placed within more experienced gangs, so that they could develop the required physical strength and learn how to handle cargo. 43 The physicality of the work was increased by the long hours and dangerous working conditions

$3^{8}$ Frederick Cooper, From slaves to squatters: plantation labor in Zanzibar and coastal Kenya, I89o-I925 (New Haven, CT, 1980); Rajnarayan Chandavarkar, Imperial power and popular politics: class, resistance and the state in India, c. I850-1950 (Cambridge, 1998).

39 Proceedings and report of the commission appointed to inquire into the cause of the present housing difficulties in Singapore, II: Evidence and memoranda (Singapore, 1918), p. 64.

$4^{\mathrm{O}}$ The role of the mandores is described in TNA, CO 273/641/6, MRCA, Sept. 1938, p. 16.

$4^{1}$ Cooper, 'Dockworkers and labour history', p. 529. On the autonomy of the gangs, see SNA, interview with Roland Milne, reel number: ooo $447 / 64 / 31$.

$4^{2}$ For general overviews that discuss the origins of Singapore's low-paid Chinese workers, see Warren, Rickshaw Coolie, pp. 14-20.

43 On the handling of dangerous goods, see SNA, interview with Hilary Vivian Hogan, reel number: $001778 / 15$. In 1936, the Singapore Free Press reported on the limited use of mechanical equipment in the port: 'Harbour board behind the times', Singapore Free Press and Mercantile Advertiser, 7 Jan. 1936, p. 7 . 
in the port, where injuries and even fatalities were common. 44 The physical aspects of the job meant that dockwork was regarded as an arduous but skilled occupation, and dockworkers later commented on the male pioneer character of the workforce, the long hours, and the physical demands of the job. 45 Historians have recorded similar views among dockworkers in other ports, where the physicality of the work and the male domination of the industry became central to dockworkers' self-perception and occupational identity. $4^{6}$ This suggests that while dockworkers were indistinguishable in socio-economic terms from Singapore's other low-paid labourers, employment in the port gave rise to a specific work culture that was a product of the social ties binding the labour gangs and the physical demands associated with work as a stevedore or wharf labourer.

Although the structure of the port industry gave rise to a distinct work culture, it does not necessarily follow that dockworkers felt compelled to act collectively to defend shared interests. Employment was highly sectional, riven by strict job hierarchies, particularly between the clerical staff, the skilled artisans employed in the dockyard department, and the rank-and-file stevedores and wharf labourers, who themselves were divided along ethnic and linguistic lines. 47 These divisions served to inhibit collective action. During the first half of the twentieth century, protests were limited to specific groups of dockworkers or disputes with individual contractors. Among the most militant workers in the port were the skilled artisans employed by the dockyard department, who were predominantly Chinese. The artisans struck numerous times during the 1920 and 1930 , including a six-week strike in 1922 and a two-month protest in $1940.4^{8}$ These strikes remained confined to the dockyard department, however, and never attracted the support of the majority rank-and-file dockworkers. Even during the late 1930s, when Singapore experienced a series of protests across multiple industries, unrest among dockworkers was restricted to separate and short-lived protests by employees of the Tanjong Pagar Labour Company and Cantonese Labour Syndicate. 49

44 As late as $195^{1}$, for example, fifteen out of sixty-six recorded industrial fatalities were dockworkers. See Annual report for the Singapore Labour Department, I95I (Singapore, 1952), p. 101 .

45 SNA, interview with Varathar Gopal, reel number: oo1238/4; SNA, interview with S. V. Shanmugam, reel number: $000981 / 1$.

$4^{6}$ David De Vries, 'The construction of the image of dock labour', in Davies et al., eds., Dock workers, pp. 604-26.

47 SNA, interview with Lim Kit Long, reel number: 002427/o6/o3.

$4^{8}$ Lee Kong Chian Reference Library, SHB, minutes of meeting of members, 17 May 1922; TNA, CO 273/614/6, MRCA, Dec. 1936, p. 20; 'History of the strike', Singapore Free Press and Mercantile Advertiser, 27 Mar. 1940, p. 2.

49 On the strikes affecting the Tanjong Pagar Labour Company and the Cantonese Labour Syndicate, see TNA, CO 275/151, Annual report for the Labour Department, Malaya 1938 (Singapore, 1939), p. 57; TNA, CO 273/641/6, MRCA, Sept. 1938, p. 16; TNA, CO 273/ 6524/12, MRCA, Mar. 1939, p. 24. 
Strikes may have exposed the divisions within the workforce during heightened moments of tension but pressures resulting from the insecure nature of port employment and the strains of working and living together as part of a labour gang were also apparent in dockworkers' daily lives. Contemporary reports and later testimony indicate that disputes between gangs and individual dockworkers were a routine part of life. $5^{\circ}$ In $195^{\circ}$, the Labour Department was called upon to mediate a long-standing disagreement within a labour gang that had become divided between its Hokkien and Teochew members. According to the Labour Department's monthly reports, the Teochew kepala (headman) had accused his Hokkien counterpart of unfairly distributing the wages, with the result that fights between the two factions had become a frequent occurrence. $5^{1}$ Such tensions echo the argument put forward by Raj Chandavarkar, who challenged overly deterministic accounts of Indian labour history by arguing that the 'aggregation of workers' within the workplace 'did not necessarily sharpen...[a] sense of common interest' but could in fact 'expose...[a] whole spectrum of differences' $.5^{2}$

This is a critical point. If occupational status did not determine behaviour, then nor should it be presumed that ethnic identity contributed to fixed patterns of behaviour. Ethno-religious divisions were certainly real, as evidenced by the segmented nature of the port industry, but the congregation of multiple migrant communities in the overcrowded neighbourhoods of Singapore also provided opportunity for interaction, the cross-fertilization of cultural practices, and the co-production of discourses relating to nationalism and citizenship. 53 Much of the literature on these subjects has focused on high-ranking Asians but cosmopolitanism was not limited to elites. Singapore's dockworkers could be termed 'working-class cosmopolitans', insofar as they embraced the cultural diversity that surrounded them even while they retained localized identities linked to ethnicity and religion.54 The district of Tanjong Pagar, where many dockworkers resided, was known as the 'gate of Singapore' because it was here that newly arrived migrants first settled.55 Living in such close proximity to other communities exposed dockworkers to different lifestyles and cultural practices: Indian dockworkers used Chinese medicine, Indian hawkers sold mee goreng, and dockworkers of all races and ethnicities gathered to watch

$5^{\circ}$ SNA, interview with Padmanabhan Ramachandran, reel number: oo $1236 / 6$; ' 8 wounded in Singapore dock fight', Straits Times, 6 Oct. $195^{\circ}$, p. 1.

$5^{1}$ National Archives College Park (NACP), 846f.o6/1 1-135o, Labour Department monthly report for Sept. 1950, American Consulate General to Department of State, 13 Nov. $195^{\circ}$.

$5^{2}$ Chandavarkar, Imperial power and popular politics, p. 8.

53 Chua Ai Lin, 'Nation, race, and language: discussing transnational identities in colonial Singapore, circa 1930', Modern Asian Studies, 46 (2012), pp. $283-302$.

54 Pnina Werbner, 'Global pathways: working-class cosmopolitans and the creation of transnational ethnic worlds', Social Anthropology, 7 (1999), pp. 17-35.

55 SNA, interview with Chanan Singh Bal, reel number: oo10o6/2. 
Malay operas and listen to Chinese storytellers. ${ }^{6}$ Singapore's dockworkers thus defy easy categorization: they were neither radical proletariat, but nor were they conservative and insular. The insecurity of port employment could lead to racial ethnic exclusivity and outright conflict. At the same time, however, living and working in the overcrowded districts of Singapore facilitated accommodation and co-operation. In short, as Sunil Amrith and Tim Harper put it, life in colonial port cities like Singapore was 'messy, inconsistent, lived rather than theorised'. 57

\section{I}

The Japanese occupation of Southeast Asia brought an end to the strikes and industrial unrest that had affected Singapore during the late 1930s, as the nascent trade union movement was driven underground and labour requisitioned according to the needs of the Japanese war economy. $5^{8}$ In the longer term, however, the Second World War served as a catalyst for the rise of popular nationalism throughout Southeast Asia after 1945. The war shattered the myth of European invincibility, contributed to widespread social and economic dislocation, and gave rise to locally rooted nationalisms in place of the diasporic nationalist movements of the interwar period.59 In the war's aftermath, populations across colonial Asia rose up in a 'connected arc of protest' against the reimposition of European imperial rule, economic hardship, and the denial of fundamental rights. ${ }^{60}$ Singapore was no exception. The island's first general strike, in January 1946, was supported by over 170 ,ooo workers and for the remainder of the year Singapore was hit by repeated strike waves as its factory and transport workers, municipal employees, and itinerant traders became increasingly militant. ${ }^{61}$ The port was one of the worst affected

$5^{6}$ SNA, interview with Padmanabhan Ramachandran, reel number: oo $1236 / 6$; SNA, interview with Sundaresan Mariammal, reel number: oo1246/4; SNA, interview with Moorthi Thatchanna, reel number: ooog9o/1; '3,ooo wharf coolies to be entertained', Straits Times, 15 May 1937 , p. 13 .

57 Harper and Amrith, 'Sites of Asian interaction', p. 257.

$5^{8}$ Leong Yee Fong, Labour and trade unionism in colonial Malaya: a study of the socio-economic and political bases of the Malayan labour movement, I930-1957 (Paulau Pinnang, 1999), pp. $106-18$.

59 Tim Harper cautions against seeing the Second World War as a 'watershed' moment, arguing that the instability wrought by the war had its roots in the economic crises and conflicts of the 1930s, 'A long view on the Great Asian War', in David Koh Wee Hock, ed., Legacies of World War II in South and East Asia (Cambridge, 2007), pp. 7-20.

6o Christopher Bayly and Tim Harper, Forgotten wars: the end of Britain's Asian empire (London, 2008), p. 190; Albert Lau, 'Nationalism in the decolonization of Singapore', in Marc Frey, Ronald W. Prussen, and Tan Tai Yong, eds., The transformation of Southeast Asia: international perspectives on decolonization (Oxford, 2003), pp. 180-96.

${ }^{6}$ Michael R. Stenson, Industrial conflict in Malaya: prelude to the communist revolt of 1948 (Singapore, 1970). 
industries. ${ }^{62}$ In contrast to the pre-war period, when strikes had been limited to protests against specific contractors, the port was hit by a series of strikes that united the workforce in a common cause, including a three-week strike by some 7, ooo dockworkers that paralysed shipping in October $1946 .{ }^{63}$

Although the British were slow to equate the unrest with an organized plot to overthrow the colonial order, the authorities were convinced that the Malayan Communist Party (MCP) was instigating the strikes. ${ }^{6}$ In mid-1946, one report stated that the General Labour Union (GLU), a trade union federation affiliated to the MCP, was 'intensifying its efforts to impose its communist controlled policy' on trade unions. Such accusations were not altogether misplaced. In the war's aftermath, the MCP's leadership had decided against armed insurgency in favour of a campaign of industrial protest. ${ }^{6}$ The port was critical to this strategy as the MCP sought to disrupt Singapore's external trade and thus undermine post-war reconstruction efforts. ${ }^{66}$ To this end, P. Veerasenan, president of the GLU, assumed responsibility for directing negotiations with the SHB during the October 1946 port strike, while party agents infiltrated the workforce in order to foment further unrest. ${ }^{67}$

Violence was central to the MCP's campaign of industrial protest. During the October 1946 port strike, which was led by the newly established Wharf Workers' Union, MCP agents vandalized the headquarters of its more conservative rival, the Wharf Workers' Mutual Help Association. ${ }^{68}$ Such incidents became routine features of the post-war strikes, as rival union leaders were attacked, strike-breakers intimidated, and rank-and-file dockworkers coerced into supporting industrial action. ${ }^{69}$ To maintain strike discipline, the MCP formed the Workers' Protection Corps (WPC), which was composed of former Malayan People's Anti-Japanese Army guerrillas and secret society members. $7^{\circ}$

${ }^{62}$ TNA, FCO 141/16870, H. A. Short, Report of inquiry into the working of the ports of Singapore, Penang and Port Swettenham, Sept. 1946, p. 2.

63 Weston Library, University of Oxford, Commonwealth and African Studies Collection (WL), MSS Indian Ocean S.251, Malaya Security Service Political Intelligence Journal (MSSPIJ), $3^{1}$ May 1946, p. 2. On the Oct. 1946 strike, see Annual report for the Singapore Labour Department, 1946 (Singapore, 1946), pp. 22-5.

64 A. J. Stockwell, 'A widespread and long-concocted plot to overthrow the government in Malaya? The origins of the Malayan Emergency', Journal of Imperial and Commonwealth History, 21 (1993), pp. 66-88.

65 Yeo Kim Wah, Political development in Singapore (Singapore, 1973), p. 206; Bayly and Harper, Forgotten wars, pp. 28-48.

66 Stenson, Industrial conflict, pp. 153-8o.

67 According to the Straits Times, Veerasenan, a Tamil, was approximately thirty years of age when he was shot and killed by colonial security forces in Malaya. 'Shot Tamil was PMFTU chief', Straits Times, 6 May 1949, p. 1.

68 WL, MSS Ind. Ocean S. 251, MSSPIJ, no. 13, $3_{1}$ Oct. 1946, p. 3; MSSPIJ, no. 14,15 Nov. 1946 , p. 2.

69 Annual report for the Singapore Labour Department, I946, p. 23; WL, MSS Ind. Ocean S. 251, MSSPIJ, no. 9, 15 May 1948, p. 340.

$7^{\circ}$ WL, MSS Ind. Ocean S. $25^{1}$, MSSPIJ, no. $16,3^{1}$ Dec. 1946 , p. 3 . 
However, although much of the violence that accompanied post-war strikes in Singapore was linked to the MCP, insecurity was also symptomatic of the social and political disorder that followed in the wake of the Japanese surrender, as the British authorities, labour contractors, secret societies, political parties, and trade unions all struggled for control of labour. ${ }^{71}$ Ethnic and gang divisions within the workforce meant that the port industry was particularly susceptible to violence. In one case, four people were killed when fighting broke out between Indian members of the Singapore Harbour Labour Union (SHLU), the successor to the Wharf Workers' Union, and Chinese gangsters linked to the ' 108 ' secret society. According to an intelligence report, the dispute arose when Indian labourers appealed to the SHLU for protection, claiming that the 108 gang were extorting money and 'interfering' with Indian women living in the SHB labour lines. $7^{2}$

The mixing of labour politics with private feuds suggests that MCP's control was not absolute. By mid-1947, it was reported that the Singapore Federation of Trade Unions was forming a 'second strong arm corps' to curb the WPC, which had 'got out of control', and many unions were establishing their own armed protection units that operated independently of the central leadership.73 This corroborates the wider point made by Tim Harper, who has argued that a close reading of the colonial archive suggests that the overall influence of the MCP was not as significant as the British authorities suspected and that the unrest of the late 1940 os was instigated as much from below as above. 74 Indeed, it was the apparent spontaneity of the mass strikes that plagued Singapore, as the island's 'invisible city' took to the streets in protest against the inequities of colonial rule, that made the unrest appear so threatening. 75 In the absence of clearly identifiable leaders, besides those who were dismissed as political agitators, the never-ending carousel of parades and rallies to which Singapore's mass of factory workers, casual labours, and street hawkers flocked made it appear as though the island was on the brink of revolution. ${ }^{6}$

What united Singapore's hitherto disparate labouring population was shared economic grievances, as low wages and shortages of essential commodities sparked wild-cat strikes and hastily arranged demonstrations. These concerns were apparent in the demands presented to the SHB by the port unions. During the 1946 strike, the Wharf Workers' Union called for a 1 oo per cent

$7^{1}$ Tim Harper, 'The politics of disease and disorder in post-war Malaya', Journal of Southeast Asian Studies, 21 (1990), p. 95.

$7^{2}$ WL, MSS Ind. Ocean S. 251, MSSPIJ, no. 8, $3_{1}^{1}$ May 1947, p. 160.

73 Ibid., p. 133 .

74 Tim N. Harper, 'Lim Chin Siong and the "Singapore story", in Tan Jing Quee, ed., Comet in our sky: Lim Chin Siong in history (Kuala Lumpur, 2001), p. 12.

75 Bayly and Harper, Forgotten wars, p. 123.

$7^{6}$ A common complaint during the post-war port strikes was that the dockworkers' representatives changed on a daily basis. See, for example, Annual report for the Singapore Labour Department, 1946 , p. 23. 
increase in wages, improved rations, and a higher cost of living allowance.77 These material demands were accompanied by a rhetoric that emphasized dockworkers' right to a dignified life. Veerasenan argued that dockworkers were entitled to a 'living wage' sufficient 'to keep body and soul together' ${ }^{7} 8$ This was in contrast to the demands that had accompanied the pre-war protests, which had been focused on ending specific abuses perpetrated by individual contractors, rather than improving working conditions for the workforce as a whole. After the war, however, the lobbying of the SHB and dockworkers' unity during the strikes suggests that the workforce was becoming increasingly politicized, with fight for improved working conditions inextricably linked to the wider anti-colonial struggle.

Dockworkers' demands were given added impetus by the rapid advance of liberation movements in neighbouring territories and the increasing prominence of discourses of anti-colonial nationalism and self-determination. This provided ordinary Singaporeans with a global context for their local struggles, transforming the cosmopolitanism that was part of dockworkers' daily lives into demands for improved political and social rights. In response to Dutch military operations in Indonesia, a multi-ethnic coalition of leftist organizations established an Indonesian Aid Committee in August 1947. As part of its campaign, the committee organized a boycott of Dutch ships that was supported by Malay, Chinese, and Indian dockworkers, and was described by one union official as a 'gesture of sympathy for the people of Indonesia', thus demonstrating how dockworkers' cosmopolitanism could inspire co-operation across ethnic divisions that, prior to 1945 , had inhibited collective mobilization in the port. 79

\section{I I}

The returning British authorities struggled to contain the post-war industrial unrest, veering between accommodation and repression. ${ }^{80}$ In accordance with the Labour government's empire-wide initiative to reform imperial labour policy, a new Labour Department was established in $1946 .^{81}$ The department was responsible for administering labour legislation, mediating disputes, and advising the trade union movement on the merits of apolitical activism. ${ }^{82}$

77 Ibid., p. 23.

$7^{8}$ 'Trade union statement on S. H. B. strike', Straits Times, 13 Nov. 1946, p. 5 .

79 WL, MSS Ind. Ocean S. 251, MSSPIJ, no. 1, $3^{1}$ Jan. 1947, p. 3; 'Labourers won't load Javabound ships', Straits Times, 6 Aug. 1947, p. 5; 'S.H.B. labour to boycott Dutch ships', Singapore Free Press, 12 Aug. 1947, p. 1; and 'Singapore dockers boycott Dutch vessels', Straits Times, 13 Aug. 1947, p. 1.

80 Harper, 'Lim Chin Siong', p. 11.

81 MRC, MSS 292/932.9/1, Trades Union Congress, Colonial Advisory Committee, no. 1 $(1947-8), 9$ Oct. 1947 .

${ }^{82}$ Nicholas J. White, 'The limits of late-colonial intervention: labour policy and the development of trade unions in 195os Malaya', Indonesia and the Malay World, 36 (2008), pp. 429-32. On the reform of imperial labour policy after 1945 and the recruitment of 'technical experts' 
The aim of such initiatives was to modernize colonial labour relations, as the colonial state granted basic labour rights in the hope of limiting trade union activity to industry-specific issues. ${ }^{8} 3$ However, in a colonial context, which necessarily entailed the denial of fundamental rights, it would prove almost impossible for the colonial government and employers to keep industrial disputes within the boundaries of the workplace. As a result, when strike action persisted during the course of 1947 , not just in Singapore but throughout Malaya, the administration's attitude began to harden. In mid-1947, the Labour Department announced that all unions would have to register by 1 May or face the loss of legal immunities. ${ }^{8} 4$ The rigorous enforcement of industrial relations legislation was accompanied by increasingly repressive police measures in response to strikes and unrest, which culminated in the declaration of the state of emergency in June 1948 and further restriction of labour freedoms. ${ }^{85}$ In other words, for all the modernizing rhetoric, late colonial labour policy remained distinctly 'colonial', characterized by the curtailment of labour rights and the granting of additional police powers to monitor and suppress organized labour.

This repressive turn in labour policy was also apparent in the port industry, where in November 1947 the SHB announced plans to abolish the contractor system. ${ }^{86}$ Rather than recruit labourers through contractors, the SHB declared its intention to employ stevedores and wharf labourers directly. Under the terms of the new system, all dockworkers would be required to register with the SHB, which would give priority to registered gangs; dockworkers would be guaranteed a forty-eight-hour week, regardless of whether there was sufficient work; and bonus payments would be introduced for meeting productivity targets. ${ }^{87}$ Officials hailed the labour reforms as 'revolutionary' and a 'great step forward' ${ }^{88}$ However, although it was framed in modernizing in terms, the registration scheme was arguably part of the colonial state's wider strategy for dealing with organized labour. Just as the industrial relations policy aimed to create clearly identifiable trade union leaders who could be trained to behave 'responsibly' and focus on economic issues, the purpose of the registration scheme was to create a stable and differentiated body of disciplined

more generally, see Frederick Cooper, Decolonization and African society: the labor question in British and French Africa (Cambridge, 1996), pp. 171-270, and Joseph Morgan Hodge, Triumph of the expert: agrarian doctrines of development and the legacies of British colonialism (Athens, $\mathrm{OH}, 2007$ ).

83 'Government policy on labour disputes', Straits Times, 3 Mar. 1947, p. 5.

84 'A warning to trade unions', Straits Times, 17 Mar. 1947, p. 4.

85 Stenson, Industrial conflict, pp. 153-80; Karl Hack, 'The origins of the Asian Cold War: Malaya 1948', Journal of Southeast Asian Studies, 4o (2009), pp. 471-96.

86 'End of SHB contract system?', Straits Times, 19 Nov. 1947 , p. 5 .

87 SNA, PSA 1872 , OO1/1946-56, SHB, Report and accounts for the year ended 3 oth June 1948 (Singapore, 1949), p. 11; Annual report for the Singapore Labour Department, I948 (Singapore, 1949), p. 14 .

88 'Revolutionary SHB pay plan', Straits Times, 18 May 1948, p. 7; TNA, CO 859/148/1, Labour and trade union organisation, p. 13. 
dockworkers. Dockworkers were classified into one of three categories: 'Permanent', 'Casuals A', and 'Casuals B'. Those dockworkers who were identified as the most 'regular' workers were classified either as 'Permanent' or 'Casuals A' and given priority when it came to the availability of employment in the belief that steady employment would improve discipline and raise productivity levels. ${ }^{89}$ The aim of the scheme was clear: to identify and separate the regular worker from the irregular, the latter regarded as a source of political unrest and social disorder. Indeed, once the scheme was implemented, thirteen mandores, including P. Govindasamy, the treasurer of the SHLU, were refused registration on the basis that they were known 'agitators'. $9^{\circ}$

In addition to regularizing employment, the SHB assumed responsibility for the contractors' obligation to provide dockworkers food, accommodation, and medical care. To this end, the SHB built a central kitchen to provide free meals; it began the process of demolishing the labour lines and replacing the bachelor quarters with family housing; and arranged for the provision of medical facilities for dockworkers and their families. ${ }^{11}$ In this respect, the SHB's reforms were about more than providing the conditions necessary for a stable family life; the aim was to separate the dockworker from the poverty that pervaded Singapore's underclass of itinerant traders and casual labourers. This is reminiscent of the 'dualism' that Cooper identified in late colonial discourse in Africa, where the colonial authorities argued that if African labourers were to become 'modern' industrial workers then they would have to be isolated from all that was presumed to be 'African' $.9^{2}$ In short, the SHB's reforms represented not just an attempt to reshape the work environment but also the domestic sphere, as the state assumed responsibility for the social reproduction of labour and the acculturation of workers to the industrial workplace.

These welfare initiatives were given added impetus by Singapore's changing demography, as the male-dominated population of the early twentieth century gave way to an increasingly settled society with a more balanced gender ratio.93 One factor contributing to this was the closing of national and colonial borders

89 TNA, FCO 141/15957, Malayan Security Service Weekly Summary (MSSWS), no. 37, 18 Sept. 1948. Frederick Cooper has made a similar argument in relation to the registration scheme that was introduced in Mombasa during the late 1940s: On the African waterfront: urban disorder and the transformation of work in colonial Mombasa (New Haven, CT, 1987), pp. 124-34, 196.

9o TNA, FCO 141/15957, MSSWS, no. 19, 15 May 1948.

$9^{1}$ SNA, PSA 1872 , OO1/1946-56, SHB, Report and accounts for the year ended 3 oth June 1948 , p. 12; SHB, Report and accounts for the year ended 3oth June I95I (Singapore, 1952), p. 10; and SNA, PSA $1872 / 002 / 1946 / 1964$, SHB, Report and accounts for the year ended 3 oth June 1957 (Singapore, 1958), p. 10 .

$9^{2}$ Cooper, Decolonization and African society.

93 According to Mary Turnbull, male adults comprised half of the population in 1931 but only one third in 1947. The increasingly settled nature of Singapore's population was particularly apparent within the Chinese community. In 1931, 36 per cent of Singapore Chinese were Straits-born; by 1947, this had increased to 6o per cent. A history of Singapore, I8I9-1975 (3rd edn, Oxford, 1980), pp. 233-4. 
throughout Asia. During the late 1940s, outward migration from India and China slowed dramatically, as the Indian and Chinese governments sought to reduce their respective states' responsibility for their overseas populations, thereby forcing Indians and Chinese living abroad to choose between returning 'home' and accepting national citizenship or seeking local citizenship. 94 Singapore also introduced its own stricter forms of immigration controls, such as the $195^{\circ}$ Immigration Ordinance, as national and colonial states throughout the region attempted to curb the older patterns of circulatory migration.95 With the SHB demanding that its labour force commit to fulltime employment, Singapore's dockworkers were faced with the choice between accepting permanent employment in the port and the associated benefits or risk of becoming 'orphans of empire' - to use Robert Cribb and Li Narangoa's oft-quoted phrase..$^{6}$

The announcement that the SHB intended to abolish the contractor system prompted short strikes by the SHLU in January and April 1948, but neither action was fully supported by the rank-and-file dockworkers, who had protested against the reimposition of the contractor system following the Japanese surrender. 97 Within two months of the April strike, 7,251 dockworkers had been registered, which included 204 pre-strike gangs and twenty-six new gangs. Of the registered dockworkers, approximately 1,700 were labourers who had been working in the port since before the war and these experienced men would form the core of the SHB's new permanent 2,ooo-strong workforce. $9^{8}$ The support for direct employment in Singapore was in stark contrast to the situation in other colonial ports, particularly in East Africa, where dockworkers resisted the introduction of registration schemes, fearing that the abolition of casual labour would erode their autonomy and the social ties that linked the labour gangs.99 In Singapore, however, dockworkers arguably had less autonomy to lose as a result of the financial and social obligations associated with the contractor system. From the dockworkers' perspective, the promise of regular wages and working hours, as well as other work-related benefits, such

94 Amrith, Crossing the Bay of Bengal, pp. 21 2-49.

95 The Ordinance, for example, required everyone, including British subjects, to secure an entry and re-entry permit in the event of temporary absence from Singapore. TNA, CO 953/ 71 /, Immigration (Control) Ordinance I950 (Singapore, 1950).

$9^{6}$ Robert Cribb and Li Narangoa, 'Orphans of empire: divided peoples, dilemmas of identity and old imperial borders in East and Southeast Asia', Comparative Studies in Society and History, 46 (2001), pp. 164-87.

97 TNA, CO 859/148/1, Labour and trade union organisation, pp. 64-5; D. F. Allen, Report on the major ports of Malaya (Kuala Lumpur, 1951), p. 6.

$9^{8}$ SNA, PSA 1872 , oO1/1946-56, SHB, Report and accounts for the year ended 3 oth June 1948 , pp. $11-12$.

99 Cooper, On the African waterfront, p. 144; John Illife, 'A history of the dockworkers of Dar es Salaam', Tanzania Notes and Records, 71 (1970), pp. 119-48; Jonathan Glassman, War of words, war of stones: racial thought and violence in colonial Zanzibar (Bloomington, IN, 201 1), pp. $120-1$. 
as housing and medical care, were preferable to the abuse and corruption associated with the contractor system. ${ }^{100}$

Following the imposition of the emergency regulations, there was a decline in strike action throughout Singapore as the MCP's leadership either fled to join the insurgency in Malaya or were driven underground. ${ }^{101}$ But the absence of organized strike action did not mean that Singapore's dockworkers were necessarily more compliant. In the decade following the introduction of the registration scheme, numerous reports expressed concern regarding the port's capacity to cope with the rising volume of trade passing through Singapore. ${ }^{102}$ Prior to the outbreak of the Second World War, individual labour gangs had been able to handle an average of twelve to fourteen tons of cargo per hour. After 1945, productivity had dropped to five to seven tons per hour and by 1957 had only recovered to nine tons per hour, even with the introduction of increased mechanization. These unsatisfactory productivity levels were attributed to various factors linked to dockworkers' performance, including: poor timekeeping, long meal breaks, inadequate supervision on the wharves, and the structure of the bonus payment system. ${ }^{103}$ The persistence of such complaints suggests that while the SHB may have been able to centralize its control over the recruitment process, it could not translate this into increased authority, with 'poor' timekeeping and low productivity levels serving as indicators of dockworkers' desire to retain autonomy over working practices.

Theft was another common complaint among the authorities. The theft of cargo had been particularly widespread in the aftermath of the war but SHB reports from the $195^{\text {os }}$ also document the lengths to which criminal gangs and individual dockworkers went to steal cargo. ${ }^{104}$ The authorities made no distinction between the activities of criminal gangs that coerced dockworkers into looting cargo and intimidated shipping agents into paying protection money, and acts of theft by individual dockworkers: both were regarded as symptomatic of dockworkers' inherent criminality. ${ }^{105}$ However, theft by an individual labourer or a gang of labourers differed from that of the organized criminal networks that operated in post-war Singapore. Theft by dockworkers was often opportunistic; they stole inexpensive items either for personal consumption or for sale on the black market, such as alcohol, food, and clothes. ${ }^{106}$ Such

\footnotetext{
${ }^{100}$ WL, MSS Ind. Ocean S. 251, MSSPIJ, no. 8, $3^{10}$ Apr. 1948, p. 280.

101 Stenson, Industrial conflict, pp. 227-35.

102 'An entrepot warning', Straits Times, 6 May 1948, p. 6.

103 'Singapore wharves: 3o percent of capacity', Straits Times, 16 Oct. 1945, p. 3; Report of the Commission of Inquiry into the port of Singapore (Singapore, 1957), pp. 16-17; TNA, FCO 141/ 16870, Short, Report of inquiry, p. 2.

${ }_{104}$ 'Law and order in the port', Straits Times, 23 Mar. 1947, p. 6. Between July 1959 and June 1960, for example, 316 offences against property were recorded in the port area. SNA, PSA 2433 24/07/2002/10, Singapore Harbour Board annual report for year I96o- I July I959 to 30 June I96o, p. 10.

105 SNA, interview with Roland Milne, reel number: ooo447/64/31.

106 SNA, PSA 2433 24/07/2002/10, SHB annual report, I96o, p. 11.
} 
acts would have been regarded by dockworkers as 'pilferage', a minor perk that was not considered a criminal act. ${ }^{107}$ The persistence of theft into the $195^{\circ}$ could be interpreted as a form of 'social banditry'. ${ }^{108}$ As the employment context changed, and the SHB introduced stricter forms of regulation to monitor labourers' performance, including the imposition of mandores on gangs that had previously operated without a foreman and an Audit Unit to counter corruption, dockworkers sought alternative forms of protest, such as theft, 'go-slow' actions, and the sabotage of industrial equipment. ${ }^{109}$ Unlike strike action, these individual acts, or 'weapons of the weak', did not depend on the solidarity of others, if left undiscovered they had the benefit of anonymity, and they served to restore dockworkers' agency at a time when the SHB was attempting to increase its control over the labour regime in the port. ${ }^{110}$

To counter the rise in criminal activity in the port, the SHB established a $15^{\mathrm{O}-}$ strong auxiliary police unit in 1947 known as the 'Aux'. A central watchtower was constructed to assist the Aux, from which the entirety of the port could be observed and radio messages relayed to officers on patrol. ${ }^{11}$ The Aux and the infrastructure introduced to support it were part of the SHB's wider strategy to transform the nature of supervision in the port. In place of the mandores' informal authority, it was now the responsibility of the Aux to control pilferage and maintain productivity, its panoptic watchtower and the uniformed police serving as potent symbols of the new disciplinary regime in the port.

The deployment of a paramilitary police unit to improve labour discipline in the port was symptomatic of the fact that for the colonial authorities 'order and efficiency' were 'parallel objectives'. ${ }^{112}$ Indeed, the eradication of the contract labour system was accompanied by a rhetoric that emphasized the importance of dockworkers abstaining from strike action and committing themselves to the regular rhythms of industrial discipline in exchange for improved access to work-related benefits. Pat Chrimes, the SHB's assistant general manager, underscored the authorities' desire to promote stability, both in terms of industrial relations and productivity:

What we want is industrial peace: we want people who will do an honest day's work in return for a day's decent wage... There will be no check on the cost of living here

107 Cooke Johnson, 'Criminality on the docks', in Davies et al., eds., Dock workers, pp. $721-45$.

${ }_{108}$ Eric J. Hobsbawm, Primitive rebels: studies in archaic forms of social movement in the I9th and 2oth centuries (Manchester, 1959).

109 SNA, interview with Roland Milne, reel number: ooo447/64/31; TNA, FCO 141/15957,

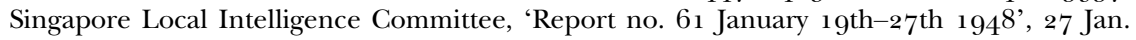
1948; TNA FCO 141/15659, 'Weekly summary, 6 Dec. $195^{2}$ to 13 Dec. $195^{2}$ ', 15 Dec. 1952; TNA FCO 141/15661, 'Weekly special branch no. 26, 23 June $195^{1}$ to 30 June $195^{1}$ ', 2 July $195^{1}$.

110 James Scott, Weapons of the weak: everyday forms of peasant resistance (New Haven, CT, 1987).

111 'May Day was “finis” for SHB looters', Straits Times, 2 May 1948, p. 6.

112 Cooper, On the African waterfront, p. 142. 
until it is realised that what you can do with a dollar depends entirely on what you are prepared to do for a dollar. ${ }^{113}$

This language of productivity and responsibility was seized upon by the trade union leadership that emerged after 1948, and union officials argued that if the SHB expected dockworkers to work regularly and increase productivity, then they should be afforded benefits consummate with their status as perman-

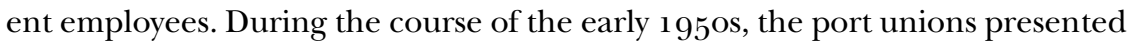
the SHB with repeated demands, including calls for holiday pay, injury and death benefits, and the provision of improved accommodation and medical care. ${ }^{14}$ Although less militant than the MCP-led SHLU had been, the unions succeeded in forcing the SHB to abandon plans for a separate pay scale for permanent and casual labourers, and secured improved housing for dockworkers following a threat to boycott the city council elections in $1953 .{ }^{115}$ Such demands had parallels throughout the empire after 1945, as colonial workers transformed the rhetoric of productivity and responsible trade unionism into a rhetoric of entitlement, insisting upon a greater share of the profits being made from their increased output. ${ }^{116}$

\section{V}

What made the strikes of $194^{6}-8$ so threatening was that the protests transcended the boundaries of the workplace, as dockworkers joined with factory workers and street hawkers in protest against poor working conditions and the denial of fundamental political rights. ${ }^{117}$ In contrast, although the SHB may not have welcomed dockworkers' escalating demands for improved workrelated benefits during the early $195^{\circ}$, such claims indicated that the abolition of the contractor system had gone some way to achieving its aim of creating a stable and differentiated workforce. This stability was short-lived. In 1955, David Marshall's populist Labour Front party triumphed in the Legislative Assembly elections. Marshall had run on a pro-labour platform with promises to improve workers' rights and repeal the emergency regulations, but the Labour Front-led government quickly found itself confronted with a rising

\footnotetext{
113 SNA, ML 1926 oo3/114/1947, Sunday Tribune, 26 Oct. 1947.

114 The SHLU collapsed following the failure of the 1948 strike but was replaced by a successor union, also known as the SHLU - although it had no ties to the MCP. TNA, FCO 141/ $1595^{1}$, supplement no. 1 to Police Intelligence Journal, 1955, Appendix D, p. 61 . On the demands

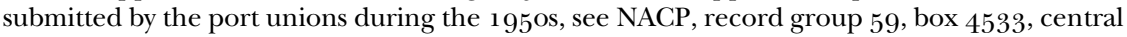
decimal files, $1955^{-9}, 846$ f.o6/1-1955, D. I. Goodwin, acting commissioner for labour, Singapore Labour Department report for the month of December 1954, 10 Jan. 1955, p. 1, enclosed in American Consulate to Department of State, 19 Jan. 1955.

115 'Harbour workers may boycott city elections', Straits Times, 12 Oct. 1953, p. 2.

116 Lisa Lindsay, 'Domesticity and difference: male breadwinner, working women and colonial citizenship in the 1945 Nigerian general strike', American Historical Review, 104 (1999), pp. $78_{3}-812$.

${ }_{117}$ Cooper, Decolonization and African society, p. 262.
} 
tide of industrial unrest instigated by trade unions affiliated to its rival, the People's Action Party (PAP). ${ }^{118}$

In a pattern of events that evoked comparison with the strike wave of the late 1940s, the pro-PAP trade unions mobilized Singapore's workers in protest against deteriorating economic conditions and the persistent infringement of workers' rights by employers. In 1955 , there were 275 recorded strikes, including a sixty-seven-day protest by the hitherto conservative Singapore Harbour Board Staff Association (SHBSA) - the union for clerical workers. ${ }^{119}$ The protest, which threatened to escalate into an island-wide general strike, resulted in an unqualified victory for the union, the SHB forced to agree to higher wages and shorter working hours. ${ }^{120}$ The union's success and newfound militancy cannot be explained without reference to its general secretary, Jamit Singh. A former University of Malaya student who was recruited by the PAP to serve as the union's secretary in 1954, Singh was part of a generation of young activists who emerged to lead the organized labour movement during the $195^{\text {os. British }}$ reports characterized Singh and his Chinese-educated compatriots, such as Lim Chin Siong and Fong Swee Suan, as communists and political radicals. ${ }^{121}$ Far from being stooges for the MCP, however, this new generation of labour leaders were anti-colonial nationalists inspired by the post-1945 upsurge in international discourses relating to self-determination and human rights. ${ }^{122}$ It was this youthful idealism and commitment to the anti-colonial cause that brought them to the attention of Lee Kuan Yew, who saw them as the ideal candidates to connect the anglophone elite of the PAP with the world of mass politics in Singapore. ${ }^{123}$

Following the 1955 strike, Singh negotiated the merger of the SHBSA with four other port unions to form the 7,00o-strong Singapore Harbour Board Workers' Union in April 1956. ${ }^{124}$ The union's potential was demonstrated in 1957 when it initiated a boycott of goods diverted to Singapore from Port Swettenham in Malaya, where the National Railway Union was involved in a 'work-to-rule' dispute. At a rally attended by an estimated 4,ooo dockworkers,

118 P.J. Thum, “'Living Buddha”: Chinese perspectives on David Marshall and his government, 1955-1956', Indonesia and the Malay World, 39 (2011), pp. $245^{-67}$.

${ }^{119}$ Liew Kai Khiun, 'The anchor and the voice of 10,000 waterfront workers: Jamit Singh in the Singapore story (1954-1963)', Journal of Southeast Asian Studies, 35 (2004), pp. 459-78

${ }^{120}$ MRC, MSS 292/932.9/2, Trades Union Congress, 'Trade union position in Singapore', Colonial Advisory Committee Paper $5 / 1\left(1954^{-5}\right), 6$ July 1955 . On the outcome of the strike, see Kai Khiun, 'The anchor', pp. $465^{-7}$.

121 TNA, FCO $141 / 15951$, supplement no. 1 to Police Intelligence Journal, 1955, Appendix D, pp. 61-2.

122 Poh Soo Kai, 'Living in a time of deception', in Poh Soo Kai, Tank Kok Fang, and Hong Lysa, eds., The $\mathrm{I}_{9} 63$ Operation Coldstore in Singapore: commemorating 5 o years (PetalingJaya, 2013), pp. 161-202.

${ }^{123}$ Harper, 'Lim Chin Siong', pp. 13-25; Pingtjin Thum, “"The fundamental issue is anticolonialism not merger": Singapore's progressive left and the creation of Malaysia', Asia Research Institute Working Paper Series, 211 (2013), pp. 1-25.

124 'Five harbour unions plan to merge', Straits Times, 16 Apr. 1956, p. 5 . 
Singh urged the union to 'fight the SHB to the finish'. To shouts of Merdeka!, the dockworkers voted in favour of Singh's call to arms, and the boycott escalated into a more general go-slow protest against the SHB. ${ }^{125}$ The subsequent commission of inquiry into the protest questioned the SBWU's legitimacy, with the result that the SHBSA was eventually designated as the principal union for dockworkers. The outcome of the protest, however, was inconsequential. ${ }^{126}$ What mattered was that these displays of solidarity with workers elsewhere in the colonial world were not expedient excuses for strike action. Demonstrations of 'transcolonial' support were a legitimate political practice that gave real meaning to local struggles to secure more basic necessities. ${ }^{127}$

In 1959, the PAP triumphed in the Legislative Assembly elections, largely as a result of its alliance with the organized labour movement. The election victory, however, masked emerging tensions within the party concerning the reform of laws relating to labour and internal security and the precise nature of Singapore's future relationship with Malaysia. ${ }^{128}$ These divisions erupted into open conflict in 1961, when the left broke away to form rival party Barisan Sosialis (Socialist Front). The split was refracted within the organized labour movement between the pro-PAP National Trade Union Congress (NTUC) and the pro-Barisan Singapore Association of Trade Unions (SATU). Despite his close association with Barisan, Singh did not affiliate the SHBSA with SATU. ${ }^{29}$ Singh's reluctance to commit the SHBSA to the Barisan cause did not protect the union from the political fallout of the PAP split. In late 1962, the registrar of trade unions launched an investigation into the administrative and accounting practices of the SHBSA. As a result of the investigation, Singh and his treasurer, Yeow Fook Yuen, were arrested on charges of misappropriating union funds. ${ }^{130}$ Singh was also attacked by pro-PAP members of the union's executive committee, who accused him of 'grandstanding' and turning the 'workers against the Government and the Harbour Board' as part of 'a vicious anti-national conspiracy'. ${ }^{13}$ Such accusations were common across the decolonizing world, where any form of opposition to the newly independent governments of Africa and Asia was branded as 'anti-national' and therefore

125 'SHB boycott', Straits Times, 22 June 1957, p. 1.

${ }_{126}$ TNA, CO 859/1146, report of a Court of Inquiry into the Trade Dispute at the SHB, Legislative Assembly sessional paper no. S 7 1957; 'SHB unions in bid to prevent walk-out', Singapore Free Press, 12 July 1958, p. 5 .

${ }_{127}$ Sunil Amrith, 'Asian internationalism: Bandung's echo in a colonial metropolis', InterAsia Cultural Studies, 6 (2005), pp. 557-69.

${ }^{128}$ Harper, 'Lim Chin Siong', pp. $25^{-41}$.

129 Following the PAP's election victory, the SHBSA had been designated as the sole trade union for all port workers. This was part of the government's drive to unify organized labour and eradicate so-called 'splinter' unions. TNA, CO 859/1536, Singapore annual report for the Department of Labour, I96o (Singapore, 1961), p. 11.

${ }^{130}$ Annual report of the Singapore Labour Department, 1962 and 1963 (Singapore, 1964), p. 19.

131 'Dissident men say Jamit Singh is "a stooge", Straits Times, 18 Aug. 1962, p. 8. 
illegitimate. ${ }^{132}$ The wider political context to the specific criticisms directed at Singh was Singapore's merger with Malaysia, to which Barisan were opposed. ${ }^{133}$ Fearing that Barisan's opposition had the potential to destabilize the merger, the PAP initiated a campaign to curb the influence of the political opposition, which culminated in Operation Coldstore in February 1963 when over 100 activists, including Singh, were detained. ${ }^{134}$

In the aftermath of Coldstore, the SHBSA petitioned the International Labour Organization (ILO), protesting against the detainees' 'arbitrary arrest' and the threat posed to human rights, freedom of thought, and trade union organization by British colonial government and local imperial agents. The Colonial Office contested this claim in its counter submission to the ILO, arguing that the arrests had been necessary to safeguard the defence and security of Singapore. ${ }^{135}$ Although historians have argued subsequently that such claims were without foundation, the ILO's Committee on the Freedom of Association concluded that the governments of Singapore, Malaysia, and Britain had no case to answer on the basis that the detainees posed a threat to national security. ${ }^{1}{ }^{6}$ The SHBSA's appeal to the ILO and its subsequent rejection by the committee highlights one of the paradoxes of decolonization. During the 1940s and $195^{\mathrm{os}}$, the language of rights and self-determination had provided a common discourse that transcended territorial boundaries. However, as colonial borders were replaced with national borders, the international discourses that had once served to undermine the moral legitimacy of imperial rule, were now regarded with suspicion and considered a threat to the primacy of state sovereignty and national development. ${ }^{137}$

Appeals to Singapore's rank-and-file dockworkers received a similarly muted response. Barisan staged a series of rallies in 1962 to protest against Singh's arrest for the misappropriation of union funds, but the SHBSA's threat to repeat the protests that had paralysed the port during the 194 os and $195^{\mathrm{O}}$

\footnotetext{
${ }^{132}$ Amrith, 'Asian internationalism', pp. 565-6.

133 Barisan was not opposed to the merger per se, rather it objected to the terms of the merger as advocated by the governments of Singapore, Malaysia, and Britain. See Thum, " "The fundamental issue",.

134 Singh was arrested as part of the operation, after which he was subjected to a travel ban and later exiled to Malaysia. TNA, FCO 141/1 2683, 'United Kingdom Commission fortnightly summary, no. 5, 2nd to $15^{\text {th }}$ Mar. 1963'. On Operation Coldstore, see Matthew Jones, 'Creating Malaysia: Singapore security, the Borneo territories and the contours of British policy, 1961-1963', Journal of Imperial and Commonwealth History, 28 (2000), pp. 85-109.

135 TNA, CO $859 / 1787$, 'Communication dated $14^{\text {th }}$ February 1963 from the Singapore Harbour Board Staff Association to the director general of the ILO'.

${ }^{13^{6}}$ TNA, CO 859/1787, 'Colonial Office, Information Department internal security measures in Singapore'.

137 Andreas Eckert, 'African nationalists and human rights, 1940s-1970s', in Stefan-Ludwig Hoffmann, ed., Human rights in the twentieth century (Cambridge, 2011 ), p. 3oo; Daniel R. Maul, Human rights, development and decolonization: the ILO, I940-I970 (Basingstoke, 2012), pp. $273^{-85}$.
} 
never materialized. ${ }^{1} 3^{8}$ Three factors may explain the dockworkers' reluctance to commit to industrial action. By early 1963 , the PAP was in the process of overseeing Singapore's transition to independence, albeit through merger with Malaysia. Therefore, whereas previously the SHB's management had been indistinguishable from the externally imposed colonial regime, this link was no longer immediately apparent. ${ }^{139}$ Linked to this, the PAP's rhetoric, which characterized strike action as an 'anti-national' act, was accompanied by threats to revoke the citizenship of government opponents. In 1963, for example, the PAP threatened to strip Sinnatampy Markandu, the president of the SHBSA, of his citizenship on the basis that he had been 'engaged in activities which are prejudicial to the security of Malaya and to the maintenance of public order'. ${ }^{\circ}$ 'The changing political context was accompanied by the delivery of tangible economic benefits to ordinary citizens as the PAP embarked upon a programme of industrialization and housing development. In the case of the port industry, Lee Kuan Yew intervened personally to award dockworkers significant pay increases in 1962 and 1963 , the second of which was accompanied by a 70 per cent vote in favour of a proposal to reduce the size of the stevedore gangs from fourteen to thirteen. ${ }^{14^{1}}$

These reforms were part of the PAP's wider development strategy. Instilled with the confidence of what James Scott termed a 'high modernist ideology', the PAP sought to manage the population and transform Singaporean society through greater state intervention. ${ }^{1} 4^{2}$ The port was critical to this policy, especially after Singapore's separation from Malaysia in $1965 .{ }^{143}$ For the PAP, the reform of employment practices and the upgrading of facilities in the port would consolidate the island's status as a regional and global trading centre and thus serve as a symbol of the party's wider modernization project. In 1964 , the SHB was replaced by the Port of Singapore Authority (PSA) and the mechanization of operations in the port, which had started in the early

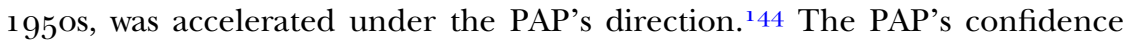
that muscular state intervention could transform Singapore's economy and society was shared by many Asian governments during this period. Whether influenced by communism or modernization theory, political elites believed

\footnotetext{
${ }_{138}$ 'The night the harbour stood still', Plebian, 13 Nov. 1962, p. 4 .

139 'Yong named chairman of SHB', Straits Times, 17 June 1961, p. 4.

140 'Harbour chief "security risk" - may lose citizenship', Straits Times, 5 July 1963, p. 7.

${ }_{141}$ 'Harbour men accept new 13 man shift system', Straits Times, 17 Aug. 1964, p. 4; ‘\$4 million pay increase for Singapore port men', Straits Times, 16 Aug, 1964, p. 5 .

${ }^{14^{2}}$ James Scott, Seeing like a state: how certain schemes to improve the human condition have failed (New Haven, CT, 1998). Loh Kah Seng has applied Scott's concept of 'high modernism' to his study of housing developing in 1960s Singapore: Squatters into citizens: the I96I Bukit Ho Swee fire and the making of modern Singapore (Singapore, 2013).

${ }^{143}$ Albert Lau, A moment of anguish: Singapore in Malaysia and the politics of disengagement (Singapore, 2000).

144 The port worker and his union: the first 40 years of Singapore Port Workers Union (Singapore, 1986), p. 32. See also Sien, 'The port of Singapore', pp. 325-30.
} 
that the pathway to modernity lay in state-led development and industrialization. ${ }^{145}$ From their testimony, it appears that dockworkers internalized the PAP's vision of modernity, drawing a sharp distinction between the poverty and abuses of colonial rule and the rising prosperity and rapid development of the post-colonial era. Hardships remained but these struggles were now linked to the collective task of nation and state building rather than anti-colonial liberation. For dockworkers, such problems required new solutions, and their focus shifted to self-sacrifice and discipline in place of strike action. ${ }^{1} 4^{6}$

Improvements to Singapore port's infrastructure were accompanied by further reforms to the labour regime as the PAP strove to implement the recommendations of the 1957 commission of inquiry. Stevedore and wharf gangs were disbanded and reformed to include both Chinese and Indian labourers. ${ }^{147}$ Not only was this policy in line with the PAP's wider strategy for managing Singapore's ethno-linguistic diversity, it also represented an attack on the social ties that bound the labour gangs. The SHB had attempted a similar manoeuvre following the 1957 go-slow protest, initially refusing to reintegrate sacked dockworkers into their former gangs for fear that they would continue to serve as agitators. ${ }^{1} 4^{8}$ Greater regulation and monitoring of dockworkers was also introduced: skilled workers, such as winchmen and mandores, were required to complete annual training courses and pass aptitude tests; personnel files were created for each worker; a unified system of pay and conditions was implemented; every worker was subject to regular medical examinations; and a retirement age of fifty-six was introduced, with gratuities available for those workers who had been employed by the SHB for ten years or more. ${ }^{149}$

These initiatives are indicative of a wider point made by Partha Chatterjee, who argues that for many post-colonial states populations came to be regarded as entities to be controlled. As a result, the participatory forms of citizenship that characterized the anti-colonial struggles of the 194 os and $195^{\text {os were replaced }}$ with a form of passive politics as populations were monitored and regulated through state-led development and welfare initiatives. ${ }^{150}$ In Singapore, the PSA's reforms represented the culmination of the changes set in motion by the SHB in 1948. Performance and productivity would no longer be controlled

145 Amrith, Migration and diaspora, p. 126.

${ }^{1} 4^{6}$ SNA, interview with Pillai Ramasamy, accession number: oo1 196/7; SNA, interview with Padmanabhan Ramachandran, accession number: oo1236/6; S. V. Shanmugam, accession number: $000981 / 1$.

147 SNA, PSA 2435/29/o7/2002, H. Hogan, deputy traffic manager (labour) to general manager, 1961; PSA $1872 / 002 / 1946 / 1964$, SHB, Report and accounts for the year ended 3oth June I962 (Singapore, 1963 ), p. 6.

${ }^{14^{8}}$ TNA, FCO $14^{1 / 1} 5^{16}$, Special Branch report to Singapore Intelligence Committee for the period 27 Nov. 1957 to 9 Dec. 1957.

149 SNA, PSA 2435/29/07/2002, H. Hogan, deputy traffic manager (labour) to general manager, 1961 .

${ }^{15}$ Partha Chatterjee, The politics of the governed: reflections on popular politics in most of the world (New York, NY, 2006), pp. 33-4. 
by the labour gangs but would instead be monitored by a centralized form of management. The dissolution of the labour gangs and introduction of regular health and performance checks were designed to encourage dockworkers not to think of themselves in terms of their collective output but to regard themselves as individuals responsible for their own performance. ${ }^{15^{1}}$

The stricter regulation of dockworkers' performance was accompanied by further limitations to trade union freedoms. In 1964, the Labour Department threatened to deregister the SHBSA, only to relent once the union revised its constitution to include clauses that prohibited executive committee members from holding official posts in political organizations, abolished the position of fulltime general secretary, and made voting compulsory for union members. All these measures, the union claimed, were designed to 'prevent communists and political opportunists from infiltrating the SHBSA in future and using it for subversive purposes' - thus echoing earlier PAP rhetoric that had branded opposition as a form of 'anti-nationalism'. ${ }^{152}$ The SHBSA continued to negotiate for improved working conditions but the union became an instrument of the state, serving to maintain industrial peace and secure workers' acceptance of further reforms. ${ }^{153}$ On one of the rare occasions that the SHBSA opposed the government, it was to protest against the PSA's use of unregistered labour in order to cope with unusually high demands in the port, thus underscoring the extent to which dockworkers were thinking of themselves as a professionalized corps of workers. ${ }^{154}$

\section{V}

Labour history has been reinvigorated by the global turn. It has encouraged historians to interrogate the basic assumptions that once informed the field, including looking beyond national frameworks to question the national character of labour movements and working-class formation. It has also opened up exciting new avenues of research, allowing historians to pay greater attention to inter-territorial networks of labour. However, the danger with these global approaches is that they can flatten and homogenize the experience of labour, emphasizing connection over disconnection, and privileging subaltern agency, co-operation, and mobility in favour of class-, gender-, and race-based hierarchies of power. This is not to deny the benefits of such insights or the valid contribution of global approaches, but to encourage labour historians to remain sensitive to the limits of global history. The task for labour historians is to focus not only the 'free' movement of labour and the associated flow of ideas, discourses, and practices across territorial borders but to investigate the role of coercion and state regulation in facilitating and restricting such

${ }^{15}$ Frederick Cooper, 'Colonizing time: work rythms and labor conflict in colonial Mombasa', in Nicholas B. Dirks, ed., Colonialism and culture (Ann Arbor, MI, 1992), pp. $230-7$.

${ }^{152}$ 'NTUC: direct instead of contract labour', Straits Times, 31 Dec. 1964, p. 5 .

153 SNA, interview with Padmanabhan Ramachandran, accession numbers: oo1 236/10-11.

154 'NTUC condemns port use of contract labour', Straits Times, 3o Dec. 1964, p. 4 . 
movements. ${ }^{155}$ Similarly, for all the focus on nodal points in the global economy, such as port cities, railway towns, and mining centres, historians should not lose sight of the fact that these were sites of both cosmopolitan exchange and places of difference and exclusion. ${ }^{1} 5^{6}$

For a period during the mid-twentieth century, Singapore's dockworkers embodied these contradictions. Many arrived in Singapore as part of the wave of Asian migration that swept across the globe from the late nineteenth century onwards. Although this process was accelerated by the expansion of European capital and imperial rule, it could not have occurred without the actions of Asian intermediaries. This was certainly the case in Singapore's port industry, where migrants secured employment through established networks that relied on shared ties of ethnicity and kinship. The importance of these networks in an industry where casual labour predominated until the late 1940s led to a deepening sense of difference as rival groups competed for scarce resources and employment opportunities. At the same time, however, dockworkers were not as parochial as traditional histories of working-class formation in Singapore have presumed. By virtue of their employment in the port, Singapore's dockworkers were more inclined than most to view their local struggles, whether in terms of their basic subsistence needs or the fight against colonial rule, in a broader global context. At no time was this more apparent than during the 1940 ond 195 os. Inspired by the upsurge in anti-colonial activism and the increasing prevalence of rights-based discourses after 1945, Singapore's dockworkers forged links, both real and imagined, with anti-colonial movements elsewhere in the imperial world. These transnational solidarities gave real meaning to dockworkers' daily lives. By the early 1960s, however, these same struggles were being articulated according to a more localized rhetoric of national development, with its emphasis on self-sacrifice and political stability. The reasons for this transformation were linked to the closing of national borders throughout Asia, Singapore's independence through merger in 1963, and the increasing prominence of state-led development theories-all of which served to delegitimize the internationalist and liberationist discourses that had characterized the anti-colonial campaigns of the 194os and 1950s. Singapore's dockworkers accepted the imposition of greater limits upon their political freedoms, reductions in the size of the workforce, and more centralized forms of management in exchange for regular employment, higher wages, and improved social security. In these circumstances, dockworkers looked inwards and the threat of strike action receded from view as the reform of the labour regime in the port, with its emphasis on discipline and productivity, became inextricably linked to the PAP's triumphant project of state building.

155 Valeska Huber, Channelling mobilities: migration and globalisation in the Suez Canal region and beyond, I869-1914 (Cambridge, 2013); Keith Breckenridge, The global politics of identification and surveillance in South Africa, I850 to the present (Cambridge, 2014).

${ }^{15}{ }^{6}$ Hyslop, 'Oceanic mobility'. 